\title{
May through July 2015 Storm Event Effects on Suspended- Sediment Loads, Sediment Trapping Efficiency, and Storage Capacity of John Redmond Reservoir
}

\section{Introduction}

The Upper Neosho and Cottonwood River watersheds, located in east-central Kansas, drain about 3,015 square miles and are the primary inflows to John Redmond Reservoir (hereinafter referred to as the reservoir). The 1964-2014 estimated sedimentation rate in John Redmond Reservoir, located in eastcentral Kansas, was almost 90 percent larger than the projected design rate of 404 acre-feet per year and resulted in a loss of about 40 percent of the conservation (multipurpose) pool storage capacity (Kansas Water Office, 2015). Loss of storage due to sedimentation in the reservoir has been estimated as anywhere from 765 acre-feet per year for 1964-2014 (Kansas Water Office, 2015) to 492 acre-feet per year for 2007-14 (Jakubauskas and others, 2014). To help maintain storage in the reservoir, the Kansas Water Office has implemented more that two dozen stream bank erosion control projects to reduce the annual sediment load entering the reservoir and initiated a dredging project to restore nearly 2000 acre-feet of storage near the dam to provide additional water supply to downstream water users (Tracy Streeter, Kansas Water Office, written commun., 2016).
During May through July 2015, precipitation in the Upper Neosho and Cottonwood watersheds delivered large quantities of runoff into the reservoir. Water was retained in the flood pool of the reservoir until late May because of downstream flooding in Oklahoma. Subsequently, water was released for the rest of the study period (June-July 2015). These changes in releases of sediment-rich water altered reservoir residence times, which directly affected reservoir sedimentation rates.

\section{Approach}

The U.S. Geological Survey (USGS), in cooperation with the Kansas Water Office and funded in part through the Kansas State Water Plan Fund, operates streamflow and continuous water-quality monitoring sites upstream and downstream from the reservoir (fig. 1). Linear regression models and data from one upstream site and one downstream site were used to compute suspended-sediment loads entering and exiting the reservoir during May through July 2015. Additionally, reservoir sediment trapping efficiency and the effects of the storms on water-storage capacity were determined. Detailed methods and results, including an analysis of sediment loads delivered from the Neosho and Cottonwood Rivers individually, can be found in Foster (2016).

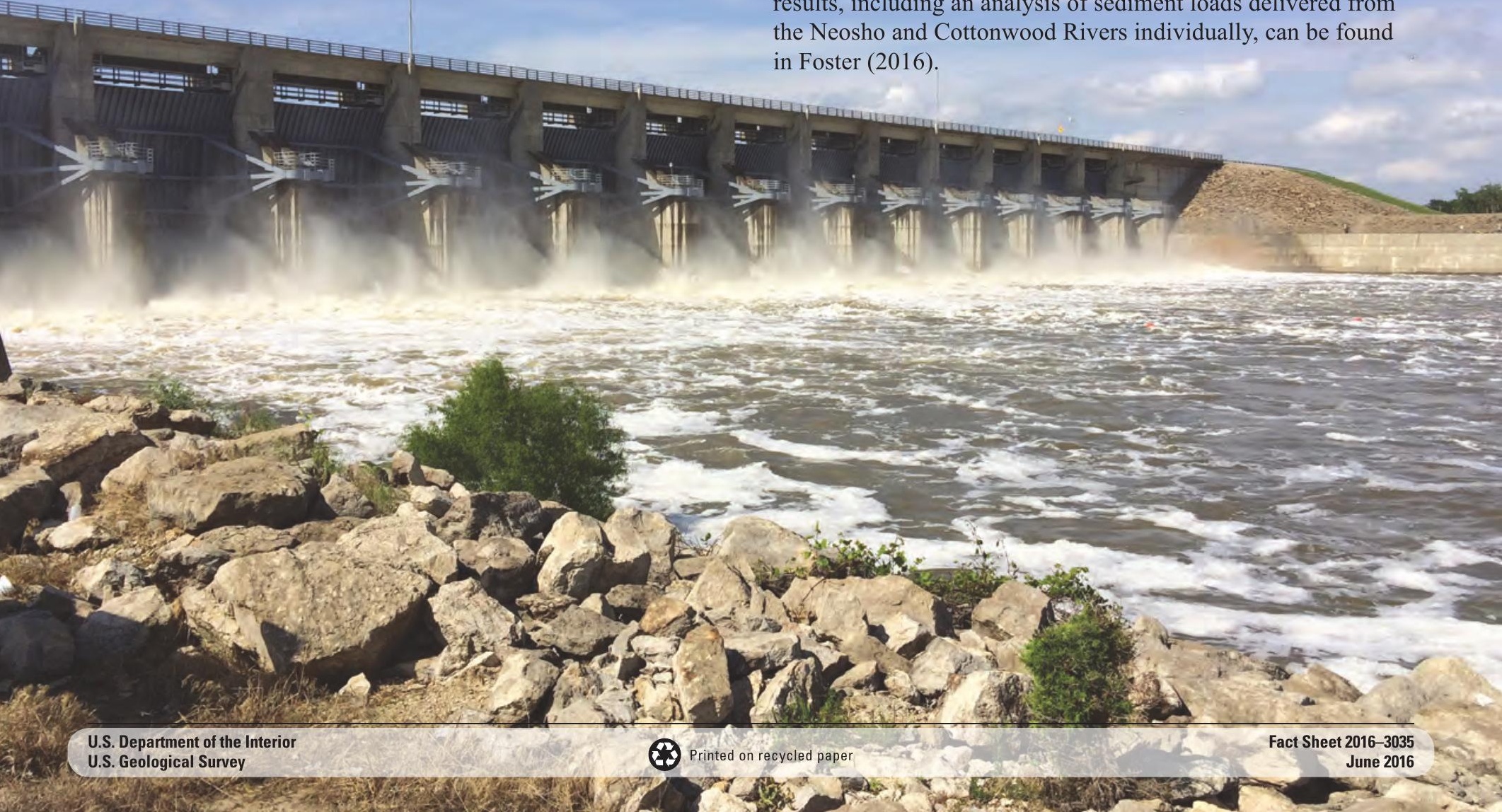




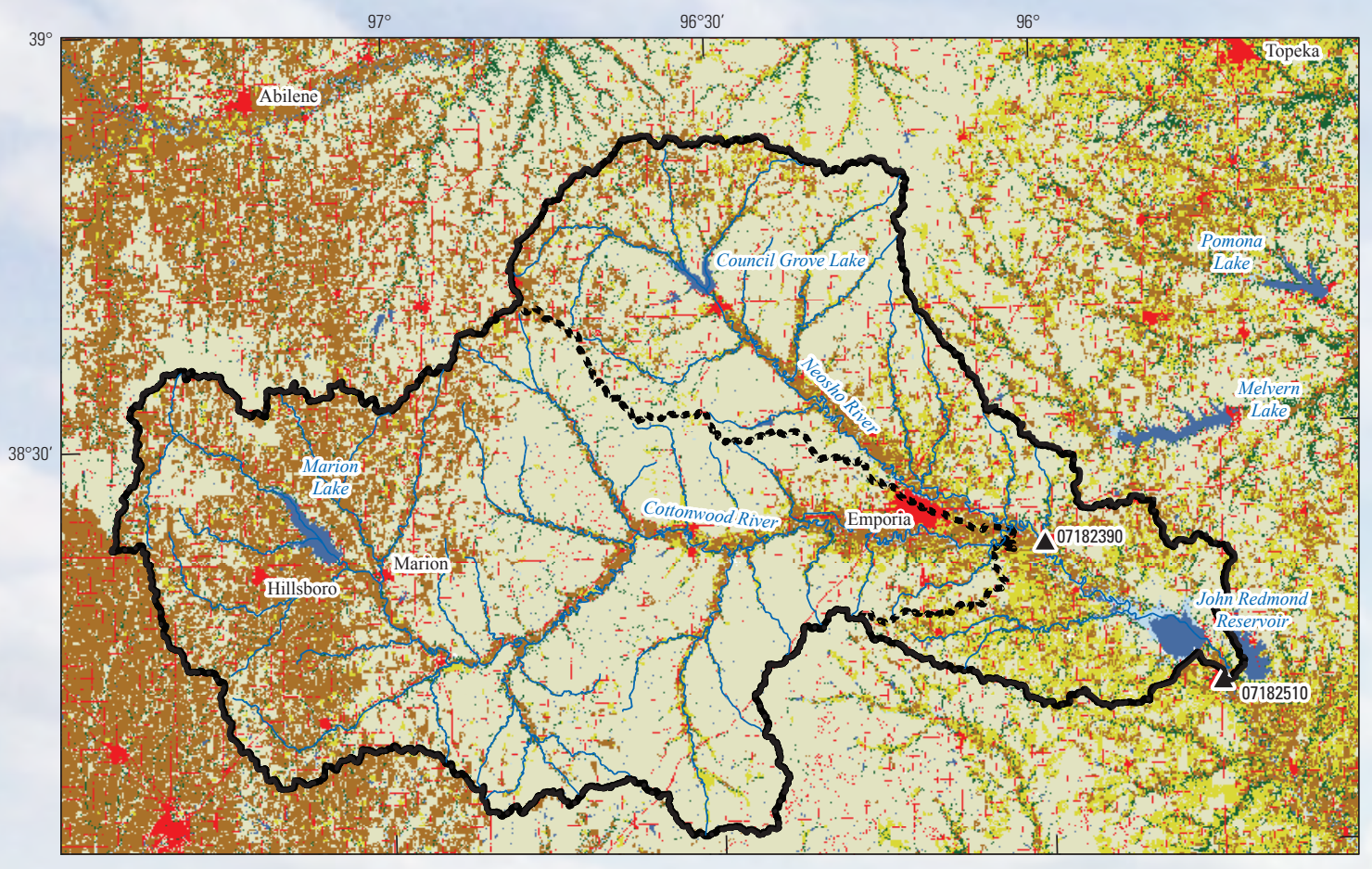

Base from U.S. Department of Agriculture 2011 National Land Cover Dataset 30-meter resolution

EXPLANATION

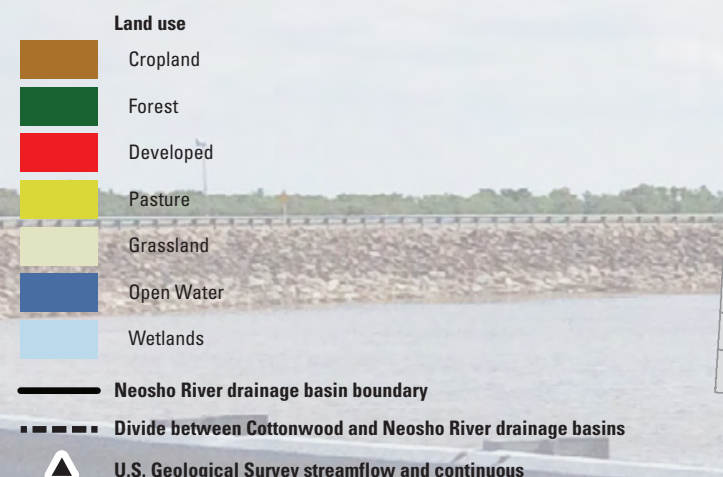

A U.S. Geological Survey streamflow and continuous water-quality site with identifier

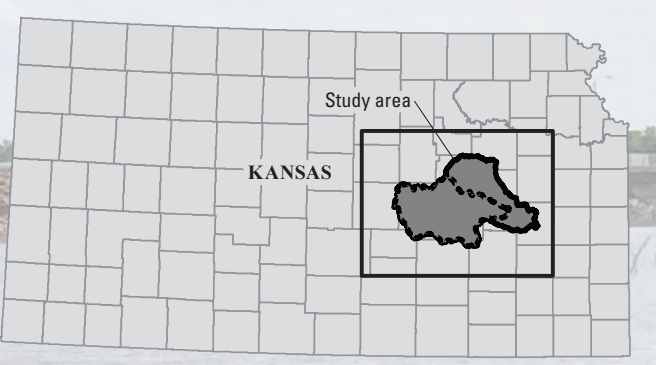

Figure 1. Location of reservoirs and two U.S. Geological Survey streamflow and continuous water-quality monitoring sites in the Upper Neosho River watershed.

\section{Streamflow}

Approximately 966,000 acre-feet of water entered the reservoir during May through July 2015 (fig. 2). Approximately 1.07 million acre-feet of water was released from the reservoir during the same period (fig. 2). The discrepancy between inflow and outflow totals can be explained by the uncertainties associated with estimating streamflow in the ungaged area of the watershed and other factors, such as in-lake evaporation, that were not able to be measured.

Fifty-five percent of the total inflows during the study period $(535,000$ acre-feet) entered the reservoir in May (fig. 2). During May, inflows mostly were retained in the reservoir because of downstream flooding in Oklahoma. The amount of water released from the reservoir in May was 72 percent less (150,000 acre-feet) than the amount of water that entered the reservoir (fig. 2).
On May 28, and throughout the rest of the study period, water was released at larger rates (up to 25,400 acrefeet per day, which is the maximum allowed for the reservoir, U.S. Army Corps of Engineers, 1996). In June, 520,000 acre-feet were released, and 396,000 acrefeet were released in July. During June and July, only 225,000 and 206,000 acrefeet entered the reservoir, respectively.

\section{Suspended-Sediment Loads}

During the 3-month study period, approximately 872,000 tons of total suspended-sediment entered the reservoir, and 57,000 tons exited the reservoir (fig. $3 A$ ). May had almost twice the inflow suspended-sediment load (559,000 tons) as June (142,000 tons) and July. (171,000 tons) combined (313,000 tons) (fig. 3B). Conversely, about 2.5 times more sediment exited the reservoir in June (24,500 tons) and July ( 16,500 tons) combined $(41,000$ tons) than in May (16,000 tons) (fig. $3 B$ ). As a 

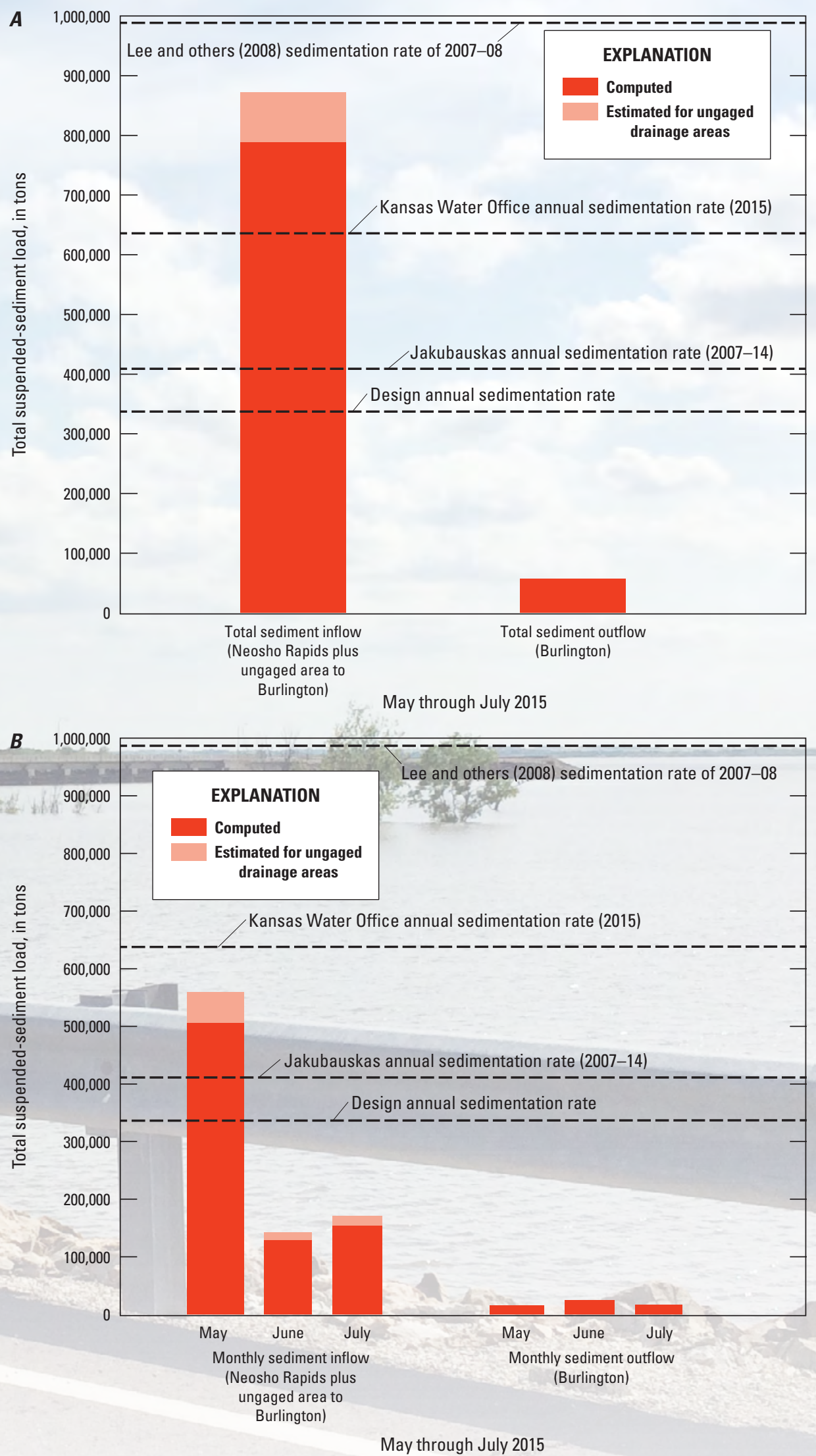

Figure 3. Computed and estimated sediment loads at gaging sites upstream and downstream from John Redmond Reservoir and selected published sedimentation rates. $A$, entire study period; $B$, by month. result of sediment trapping in the reservoir, suspended-sediment loads into the reservoir were between 5 and 34 times larger than suspended-sediment loads exiting the reservoir, even during the periods with the largest reservoir releases. The suspendedsediment load entering the reservoir in May alone was greater than the annual design sedimentation rate (Kansas Water Office, 2015) and estimated annual sedimentation rate from 2007 through 2014 (Jakubauskas and others, 2014).

\section{Sediment Trapping Efficiency}

The average sediment trapping efficiency of the reservoir during the study period was 93 percent but ranged from 97 percent during May, when waters were being retained in the reservoir, to 83 percent during June, the month of maximum releases (fig. 4). A similar study conducted in 2007-8 (Lee and others, 2008) estimated trapping efficiency to be 91 percent. The range (83 to 97 percent) of sediment trapping efficiencies during this study was directly related to reservoir outlet operations; trapping efficiency was lowest when reservoir releases were highest. The relation between reservoir releases, water residence time, and sediment trapping efficiency may be used to manage reservoir sedimentation.

\section{Effect on Reservoir Storage Capacity}

Utilizing a mean bulk density for the reservoir of 38.2 pounds per cubic foot (Juracek, 2010), and 815,000 tons of sediment retained during the 3 -month study period, 980 acre-feet of reservoir storage was lost because of sediment deposition during May through July 2015, assuming that all sediment was deposited in the multipurpose pool area. About 1.6 percent of the conservation-pool storage capacity of the reservoir, therefore, was lost during the 3-month study period (utilizing the storage tables in Jakubauskas, 2014). Slightly more than 1 percent was lost during May alone. It is likely some percentage of sediment was deposited in flood-inundated areas upstream from the reservoir and not in the reservoir, although the amount cannot be quantified by this analysis. Storage lost during this 3 -month period was 1.3 times larger than the estimated annual storage losses of 765 acre-feet per year for 1964-2006 (Kansas Water Office, 2015), 


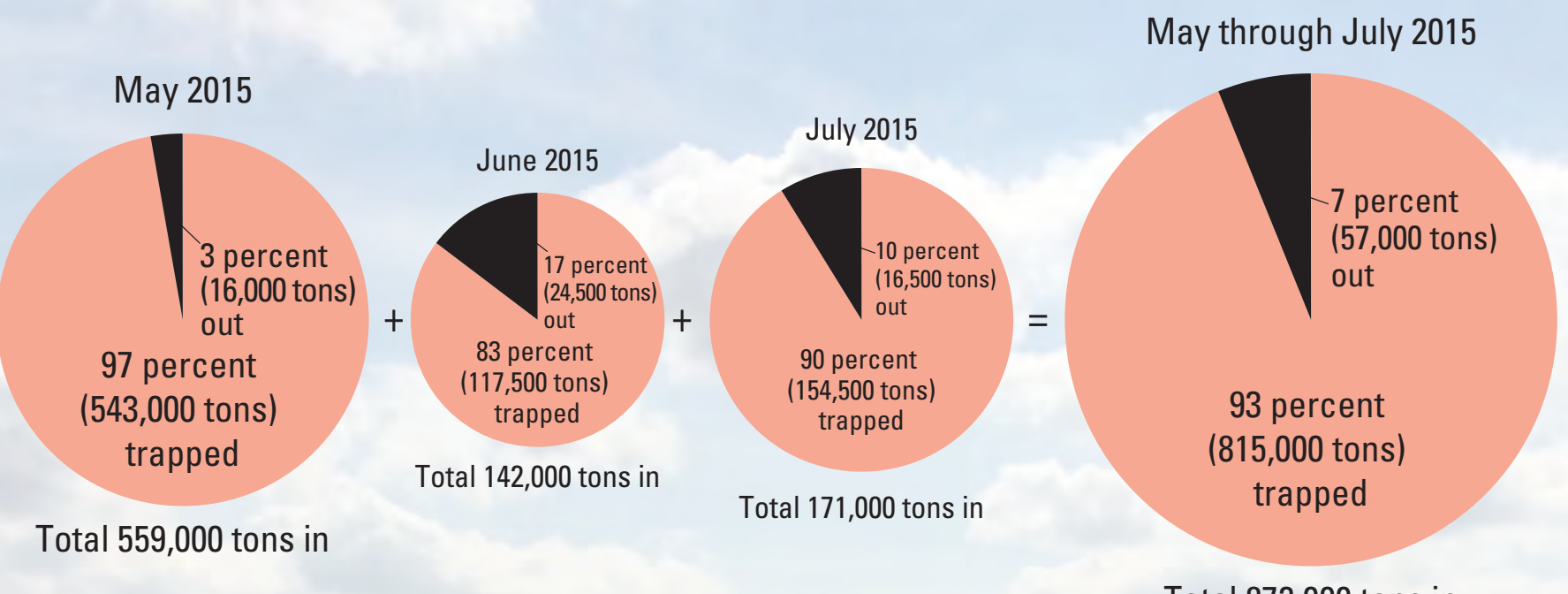

Total 872,000 tons in

Figure 4. Sediment trapping efficiency of John Redmond Reservoir during May through July 2015.

2 times larger than the 492 acre-feet per year for 2007-2014 (Jakubauskas and others, 2014), and 2.4 times larger than the design rate of 404 acre-feet per year. These results are similar to other reservoir studies in Kansas (Foster and others, 2012; Stone and others, 2015) that indicate large volumes of sediment are delivered to reservoirs in short periods of time (hours or days). Large events, coupled with minimal releases, can have a substantial effect on reservoir storage.

\section{References Cited}

Foster, G.M., 2016, Effect of May through July 2015 storm events on suspended sediment loads, sediment trapping efficiency, and storage capacity of John Redmond Reservoir, east-central Kansas: U.S. Geological Survey Scientific Investigations Report 2016-5040, 10 p., [Also available at http://dx.doi.org/10.3133/sir20165040.]

Foster, G.M., Lee, C.J., and Ziegler, A.C., 2012, Sediment transport to and from small impoundments in northeast Kansas, March 2009 through September 2011: U.S. Geological Survey Scientific Investigations Report 2012-5269, 38 p. [Also available at http://pubs.usgs. gov/sir/2012/5269.]

Jakubauskas, M., deNoyelles, J., and Martinko, E., 2014, Bathymetric survey of John Redmond Reservoir, Coffey County, Kansas: Applied Science and Technology for Reservoir Assessment (ASTRA) Program, Report 2014-01, 17 p.

Juracek, K.E., 2010, Sedimentation, sediment quality, and upstream channel stability, John Redmond Reservoir, east-central Kansas, 1964-2009: U.S. Geological Survey Scientific Investigations Report 2010-5191, 34 p.

Kansas Water Office, 2014, Final Programmatic Environmental Impact Statement (FPEIS): Kansas Water Office Web site, accessed October 20,2014, at http://www.kwo.org/projects_programs/ JohnRedmondDredging/rpt_JohnRedmond_Dredge_DPEIS ATR_090314_sm.pdf.
Kansas Water Office, 2015, John Redmond Lake Reservoir Information Sheet: Kansas Water Office publication, accessed August 2015 at http://www.kwo.org/reservoirs/reservoirfactsheets/Rpt_JohnRedmond_2015.pdf.

Lee, C.J., Rasmussen, P.P., and Ziegler, A.C., 2008, Characterization of suspended-sediment loading to and from John Redmond Reservoir, east-central Kansas, 2007-2008: U.S. Geological Survey Scientific Investigations Report 2008-5123, 25 p.

Stone, M.L., Juracek, K.E., Graham, J.L., and Foster, G.M., 2015, Quantifying suspended sediment loads delivered to Cheney Reservoir, Kansas-Temporal patterns and management implications: Journal of Soil and Water Conservation, v. 70, no. 2, p. 91-100.

U.S. Army Corps of Engineers, 1996, Water control manual for John Redmond Dam and Reservoir-Neosho River, Kansas: Dallas, Texas, U.S. Army Corps of Engineers, Southwestern Division, $172 \mathrm{p}$.

\section{By Guy M. Foster and Lindsey R. King}

For more information, contact:

Director, USGS Kansas Water Science Center

4821 Quail Crest Place

Lawrence, Kansas 66049

(785) 842-9909

http://ks.water.usgs.gov/ 